\title{
KARYAWAN INOVATIF MENGHADAPI COVID-19: BAGAIMANA PERAN PENGATURAN KERJA FLEKSIBEL, BEBAN KERJA, DAN KETERIKATAN KERJA?
}

\author{
Pricilla Mourine Ham \& Arum Etikariena
}

Fakultas Psikologi, Universitas Indonesia, Jln. Margonda Raya, Pondok Cina, Beji, Depok, 16424, Indonesia

\section{INNOVATIVE EMPLOYEES IN DEALING WITH COVID-19: WHAT ARE THE ROLES OF FLEXIBLE WORK ARRANGEMENTS, WORKLOADS, AND WORK ENGAGEMENT?}

\begin{abstract}
The COVID-19 pandemic exposes Indonesian companies with new challenges, which requires an innovative approach. This study aims to examine the role of work engagement in mediating the relationship between flexible work arrangement and innovative work behavior, where workload is included as a possible moderator of the relationship between flexible work arrangement and role engagement. Data of 262 employees in Indonesia $\left(\mathrm{M}_{\text {age }}=\right.$ $33.70 ; \mathrm{SD}=10.79)$ was collected online, where their responses indicated levels of innovative work behavior, work engagement, workload, and their attitudes towards flexible work options. The findings showed that low workloads facilitates employees who practice flexible work arrangements to be more engaged to their jobs, which then increases their innovative behavior. The finding presents valuable information for Indonesian organizations, particularly when adopting flexible working arrangement, to adjust their employees' workload that would promote their work engagement and innovation.
\end{abstract}

Manuscript type: Original Research

\author{
Article history: \\ Received 18 September 2020
}

Received in revised form 22 October 2020

Accepted 12 January 2021

Available online 10 April 2021

\section{Keywords:}

COVID-19

flexible work arrangement

innovative work behavior

quantitative workload

work engagement

\begin{abstract}
Abstrak
Pandemi COVID-19 menghadapkan perusahaan pada tantangan baru. Salah satu cara yang dapat dilakukan oleh perusahaan untuk bertahan adalah dengan berinovasi. Oleh karena itu, penelitian ini bertujuan untuk menguji peran keterikatan kerja dalam memediasi hubungan antara pengaturan kerja yang fleksibel dengan perilaku kerja yang inovatif, di mana beban kerja diajukan sebagai variabel moderator dalam hubungan antara pengaturan kerja fleksibel dan keterikatan kerja. Metode pengumpulan data dilakukan melalui survei secara daring untuk mengukur perilaku kerja inovatif, pengaturan kerja yang fleksibel, keterikatan kerja, dan beban kerja kuantitatif. Partisipan penelitian ini adalah 262 orang karyawan di Indonesia $\left(M_{a g e}=33.70 ; S D=10.79\right)$. Hasil penelitian menunjukkan bahwa beban kerja yang rendah dapat membantu karyawan yang menerapkan pengaturan kerja fleksibel untuk menjadi lebih terikat dengan pekerjaannya sehingga dapat meningkatkan perilaku inovatif. Hasil studi ini menyajikan informasi yang bermanfaat bagi perusahaan di Indonesia, terutama yang menerapkan pengaturan kerja yang fleksibel, dalam mengatur beban kerja karyawan sehingga karyawan tetap merasa menjadi bagian di dalam pekerjaannya dan mampu berinovasi.
\end{abstract}

Kata Kunci: beban kerja kuantitatif, COVID-19, keterikatan kerja, pengaturan kerja yang fleksibel, perilaku kerja inovatif

\section{Dampak dan Implikasi dalam Konteks Ulayat}

Pengaturan kerja fleksibel yang diterapkan oleh kebanyakan perusahaan di Indonesia selama pandemi COVID-19 merupakan sebuah praktik baru. Beberapa perusahaan cenderung melihat praktik kerja fleksibel sebagai praktik yang menurunkan kinerja karyawan karena berkurangnya pengawasan langsung yang dapat dilakukan. Mempertimbangkan natur dari pandemi, pengaturan kerja fleksibel mungkin masih akan diterapkan dalam jangka waktu panjang. Oleh karenanya, hasil studi ini dapat memberikan informasi yang bermanfaat bagi perusahaan dalam meningkatkan produktivitas karyawan selama pengaturan kerja fleksibel, khususnya dalam mempromosikan perilaku inovatifnya. 


\section{PENDAHULUAN}

Indonesia merupakan salah satu dari 210 negara di dunia yang terkonfirmasi memiliki kasus positif virus korona (COVID-19) (Worldometer, 2020). Bukan hanya dampak medis, pandemi COVID-19 juga memberikan dampak negatif sekunder pada ekonomi dunia (Mehta, 2020), termasuk Indonesia (Laucereno, 2020). Dampak negatif tersebut di antaranya adalah penurunan ekspor dan impor, terganggunya bisnis pariwisata, serta penurunan produktivitas perusahaan pada skala besar (Laucereno, 2020). Selain itu, COVID-19 juga memberikan dampak terhadap keberlangsungan tenaga kerja. Hingga bulan April 2020, sebanyak 1,021,594 karyawan dari 3,711 perusahaan di Jakarta bekerja dengan sistem work from home (WFH) sebagai upaya penanganan dan pencegahan penyebaran COVID-19 (Dinas Ketenagakerjaan dan Transmigrasi DKI Jakarta, 2020). Hal tersebut menunjukkan bahwa perusahaan sedang dihadapkan pada tantangan untuk dapat bertahan pada masa krisis seperti ini.

Penerapan pengaturan kerja yang fleksibel, seperti WFH, menghadirkan tantangan tersendiri bagi beberapa perusahaan di Indonesia (Fachriansyah, 2020). Beberapa perusahaan melihat pengaturan kerja yang fleksibel sebagai ancaman karena keterbatasannya dalam mengawasi karyawan secara langsung (Himawan dkk., 2020). Beberapa karyawan juga belum memiliki sikap yang positif serta kesiapan untuk menerapkan pengaturan kerja yang fleksibel, seperti: merasa cemas, kurang bersemangat, dan lelah karena adanya penambahan beban kerja selama bekerja dari rumah (Fachriansyah, 2020). Meski begitu, karyawan tetap dituntut untuk menunjukkan produktivitas di perusahaan.

Melakukan inovasi merupakan salah satu faktor yang dapat membantu perusahaan untuk bertahan dalam kondisi krisis (Lang, 2020). Beberapa perusahaan telah memasukan inovasi sebagai bagian dalam uraian pekerjaan karyawan (Scott \& Bruce, 1994) karena perusahaan perlu untuk siap akan strategi baru dalam bisnis (Finn, 2020). Elemen penting dari inovasi berasal dari individu yang dapat menciptakan, mengembangkan, dan memodifikasi sebuah ide atau gagasan yang berguna bagi perusahaan (Scott \& Bruce, 1994). Oleh karena itu, karyawan yang inovatif dipandang dapat membantu perusahaan untuk menciptakan, mempromosikan, dan merealisasikan ide dan gagasan yang berguna, sehingga dapat meningkatkan prosedur kerja, produk, serta layanan yang dihasilkan oleh perusahaan (Janssen, 2000).

Perilaku inovatif dalam konteks dunia kerja dikenal dengan istilah perilaku kerja inovatif, yang didefinisikan sebagai proses bertahap yang terdiri dari perilaku berbeda pada tiap tahapannya 
(Scott \& Bruce, 1994). Tahapan tersebut terdiri dari: 1). melahirkan ide (idea generation), yaitu ketika karyawan menciptakan atau mengembangkan ide baru yang berguna bagi perusahaan, 2). mempromosikan ide (idea promotion), yaitu ketika karyawan terlibat dalam aktivitas sosial untuk mendapatkan dukungan atas ide yang telah dikembangkan, dan 3). mewujudkan ide (idea realization), yaitu ketika karyawan telah berhasil mewujudkan sebuah model yang dapat diterapkan dalam perusahaan (Janssen, 2000).

Di sisi lain, keterlibatan karyawan dalam melakukan inovasi juga dapat dianggap sebagai tuntutan kerja tambahan bagi karyawan. Kendati demikian, tuntutan kerja tersebut sesungguhnya dapat dimanfaatkan untuk meningkatkan motivasi kerja (Messmann dkk., 2017). Hal ini dapat dijelaskan melalui Job Demands-Resource Model (Model JD-R) yang memandang bahwa tuntutan kerja (job demands) dapat berdampak pada peningkatan motivasi karyawan atau justru melelahkan karyawan. Tuntutan kerja juga dapat memaksimalkan peran dari sumber daya pekerjaan (job resources) yang tersedia bagi karyawan (Bakker \& Demerouti, 2017). Oleh sebab itu, pada penelitian ini beban kerja kuantitatif turut diukur untuk memaksimalkan peran dari pengaturan kerja yang fleksibel terhadap keterikatan kerja, sehingga pada akhirnya dapat berdampak pada perilaku kerja inovatif. Selain itu, dijelaskan pula bahwa salah satu kelebihan dari Model JD-R adalah fleksibilitasnya, sehingga seluruh aspek yang berhubungan dengan karakteristik pekerjaan dapat digolongkan menjadi sumber daya pekerjaan (job resources) ataupun tuntutan pekerjaan (job demands) (Bakker \& Demerouti, 2014).

Berkaitan dengan hal tersebut, salah satu sumber daya pekerjaan yang saat ini marak dilakukan karena adanya dampak dari COVID-19 adalah pengaturan kerja yang fleksibel (flexible work arrangement). Semenjak COVID-19, terjadi beberapa perubahan terkait dengan sistem kerja di Indonesia. Pengaturan kerja yang fleksibel merupakan metode bekerja alternatif yang memungkinkan karyawan untuk menyelesaikan pekerjaan di luar batasan waktu dan/atau tempat pada hari kerja normal (Shockley \& Allen, 2007). Terdapat dua bentuk pengaturan kerja fleksibel yang umum dilakukan, yaitu flextime (kebebasan terkait waktu bekerja) dan flexplace (kebebasan terkait lokasi bekerja) (Shockley \& Allen, 2007). Salah satu bentuk flexplace yang paling umum dilakukan adalah Work From Home (WFH) (Chen \& Fulmer, 2017).

Pengaturan kerja yang fleksibel (salah satunya WFH) dikatakan dapat menghilangkan batasan fisik maupun psikologis antara pekerjaan dan kehidupan pribadi (Chen \& Fulmer, 2017). Hal tersebut dapat mempersulit karyawan dalam menjaga perannya dalam bekerja maupun mengatur kehidupan pribadinya. Selain itu, hilangnya batasan antara pekerjaan dan kehidupan pribadi juga dapat 
menyebabkan karyawan menjadi lebih sulit merasakan keterikatan dengan pekerjaannya, sehingga perlu bagi karyawan untuk menjaga batasan antara pekerjaan dengan kehidupan pribadinya agar tidak terganggu ketika menjalankan salah satu perannya (Kossek dkk., 2006). Di sisi lain, dampak positif dari pengaturan kerja yang fleksibel adalah membantu karyawan dalam mengelola tanggung jawab pekerjaan dan tanggung jawab pribadi secara lebih efektif (Allen \& Shockley, 2009). Selain itu, pengaturan kerja yang fleksibel juga dapat meningkatkan keseimbangan antara kehidupan pribadi dan kehidupan pekerjaan (work-life balance) (Hayman, 2009). Ugargol dan Patrick (2018) menyebutkan bahwa kebebasan yang diberikan dalam pengaturan kerja yang fleksibel juga dapat meningkatkan keterikatan kerja dan performa karyawan karena ketika karyawan diberikan kebebasan terkait pengaturan kerja yang fleksibel, maka karyawan memiliki lebih banyak sumber daya untuk mencapai tujuan dalam bekerja, serta memiliki kontrol yang lebih besar akan pekerjaannya. Hal tersebut dapat membantu karyawan untuk memiliki lebih banyak energi yang ditujukan pada pekerjaannya, sehingga dapat memengaruhi keterikatan kerja. Oleh karena itu, dapat dikatakan bahwa ketika karyawan dapat memanfaatkan kebebasan dalam mengontrol pekerjaannya, karyawan dapat mencapai keterikatan kerja.

Keterikatan kerja merupakan kondisi mental karyawan yang merasa penuh dengan energi fisik (vigor), antusias mengenai aktivitas pekerjaan dan hal-hal yang dilakukan selama bekerja (dedication), dan terlibat secara mendalam pada aktivitas kerja yang dilakukan (absorption) (Bakker \& Demerouti, 2017). Karyawan dengan tingkat keterikatan kerja yang tinggi memiliki kecenderungan untuk mencari ide baru yang inovatif, sehingga dapat meningkatkan efektivitas organisasi (Park dkk. 2014). Secara spesifik, karyawan perlu untuk berkonsentrasi dan terlibat secara mendalam pada pekerjaannya untuk menciptakan ide dan gagasan. Selain itu, mengingat bahwa perilaku kerja inovatif merupakan proses yang memerlukan perilaku berbeda pada tiap tahapannya, karyawan perlu untuk memiliki ketahanan mental agar tidak teralihkan dari pekerjaannya. Terakhir, untuk dapat memberikan upaya kognitif dan emosional secara terus-menerus, karyawan perlu untuk memiliki rasa bangga terhadap pekerjaannya dan merasa bahwa upaya yang dikeluarkannya bermanfaat (Agarwal dkk., 2012). Oleh karena itu, dapat dikatakan bahwa keterikatan kerja perlu dimiliki oleh karyawan untuk dapat menjadi inovatif (Park dkk., 2014).

Mengacu pada Model JD-R, dijelaskan pula bahwa sumber daya pekerjaan (dalam hal ini pengaturan kerja yang fleksibel) dapat memengaruhi keterikatan kerja, ketika tuntutan pekerjaan tinggi (Bakker \& Demerouti, 2017). Pekerjaan yang mengkombinasikan sumber daya dengan tuntutan kerja yang tinggi dapat memberikan kesempatan bagi karyawan untuk mempelajari hal baru 
dan meningkatkan motivasi karyawan. Adanya tuntutan pekerjaan yang tinggi dapat membuat sumber daya kerja lebih bermanfaat dan mempengaruhi motivasi karyawan. Salah satu bentuk tuntutan pekerjaan adalah beban kerja (Bakker \& Demerouti, 2014), yang dapat diukur dengan jumlah waktu yang dihabiskan untuk bekerja, tingkat produksi, atau bahkan tuntutan mental dari pekerjaan yang dilakukan (Spector \& Jex, 1998). Sehubungan dengan hal tersebut, Spector dan Jex (1998) mengembangkan alat ukur Quantitative Workload Inventory (QWI) untuk mengukur tempo dan volume atau banyaknya pekerjaan yang dirasakan oleh karyawan.

Penelitian serupa yang mengacu pada Model JD-R telah dilakukan oleh De Spiegelaere dkk. (2016) yang meneliti mengenai pengaruh dari job autonomy (keleluasaan cara kerja, keleluasaan jadwal bekerja, waktu kerja, tempat kerja) terhadap keterikatan kerja dan perilaku kerja inovatif. Work time autonomy dan locational autonomy pada penelitian tersebut merupakan jenis dari pengaturan kerja yang fleksibel. Hasil penelitian menunjukkan bahwa work time autonomy tidak memiliki hubungan yang signifikan, baik dengan keterikatan kerja maupun perilaku kerja inovatif. Sementara itu, locational autonomy diketahui hanya memiliki hubungan langsung yang signifikan dengan perilaku kerja inovatif tanpa melalui mediator keterikatan kerja. Lebih lanjut, karena kedua jenis pengaturan kerja yang fleksibel tersebut diketahui tidak memiliki hubungan yang signifikan dengan keterikatan kerja, terdapat ketidaksesuaian antara hasil dari penelitian dengan Model JD-R yang digunakan sebagai landasan. Berkaitan dengan hal tersebut, pada penelitian ini ditambahkan peran beban kerja kuantitatif sebagai moderator antara pengaturan kerja yang fleksibel dengan keterikatan kerja. Adanya peran moderator tersebut diharapkan dapat membantu meningkatkan dampak positif dari pengaturan kerja yang fleksibel terhadap keterikatan kerja, sehingga karyawan dapat memunculkan perilaku kerja inovatif.

Di sisi lain, penerapan pengaturan kerja yang fleksibel di Indonesia tampaknya masih memerlukan beberapa penyesuaian agar dapat berjalan dengan lebih efektif. Beberapa karyawan di Indonesia memiliki kebiasaan untuk tidak bekerja apabila berada di rumah dan masih memerlukan pedoman kerja yang baku (seperti jam kerja \& bimbingan dari atasan) (Anell \& Hartmann, 2007). Selain itu, adanya tanggapan negatif karyawan karena penambahan beban kerja selama menerapkan pengaturan kerja yang fleksibel (Fachriansyah, 2020), membuat perusahaan perlu mempertimbangkan tingkat beban kerja yang diberikan kepada karyawan. Oleh karena itu, melihat perbedaan pada beberapa penelitian yang telah dilakukan, maka hipotesis dalam penelitian ini adalah keterikatan kerja berperan secara signifikan sebagai mediator yang dimoderasi oleh beban kerja kuantitatif pada hubungan antara pengaturan kerja yang fleksibel dengan perilaku kerja inovatif. 


\section{METODE}

\section{Partisipan}

Jumlah partisipan dalam penilitian ini adalah 262 orang. Berdasarkan pengukuran ukuran jumlah sampel menggunakan aplikasi $\mathrm{G}^{*}$ Power dengan ukuran efek sedang .15, dengan asumsi tingkat signifikansi 5\%, dan kekuatan statistik 95\%, jumlah sampel minimal yang dibutuhkan adalah 107 orang (Faul dkk., 2007). Oleh karena itu, pada penelitian ini telah memenuhi jumlah sampel minimal. Adapun karakteristik partisipan dalam penelitian ini adalah karyawan yang telah bekerja selama minimal 6 bulan di perusahaan di Indonesia dan pernah atau sedang menerapkan pengaturan kerja yang fleksibel (dalam hal waktu maupun lokasi bekerja). Partisipan dalam penelitian ini dapat memiliki latar belakang pekerjaan yang bervariasi dan berasal dari bidang perusahaan yang bervariasi pula. Teknik pengambilan sampel yang digunakan adalah non-probability sampling karena jumlah populasi tidak sepenuhnya diketahui, sehingga pengambilan sampel dilakukan dengan berdasarkan pada kemudahan akses untuk mendapatkan partisipan (Gravetter \& Forzano, 2012). Tabel 1 merangkum gambaran umum partisipan dalam penelitian ini. Mayoritas partisipan dalam penelitian ini adalah perempuan, berusia antara 20-34 tahun, serta sedang bekerja dalam perusahaan selama kurang dari 2 tahun.

Tabel 1.

Gambaran Umum Partisipan Berdasarkan Data Demografis

\begin{tabular}{ccccc}
\hline Aspek Demografis & $\mathbf{N}$ & $\mathbf{\%}$ & Mean & SD \\
\hline Jenis Kelamin & & & - & - \\
Laki-laki & 117 & 44.66 & & \\
Perempuan & 145 & 55.34 & & \\
Usia & & & 33.70 & 10.79 \\
$20-34$ & 159 & 60.68 & & \\
$35-50$ & 78 & 29.77 & & \\
$50-65$ & 25 & 9.54 & & - \\
Masa Kerja & & & \\
$<2$ tahun & 100 & 38.17 & & \\
$2-10$ tahun & 94 & 35.88 & & \\
$>10$ tahun & 68 & 25.95 & & \\
\hline
\end{tabular}

\section{Desain}

Penelitian ini merupakan penelitian kuantitatif dengan desain non-eksperimental. Variabel independen yang digunakan adalah pengaturan kerja yang fleksibel (FWA), variabel dependen adalah perilaku kerja inovatif, variabel mediator adalah keterikatan kerja, dan variabel moderator adalah 
beban kerja kuantitatif. Data diperoleh menggunakan kuesioner self-report yang disebarkan secara daring. Berikut adalah bagan model penelitian ini.

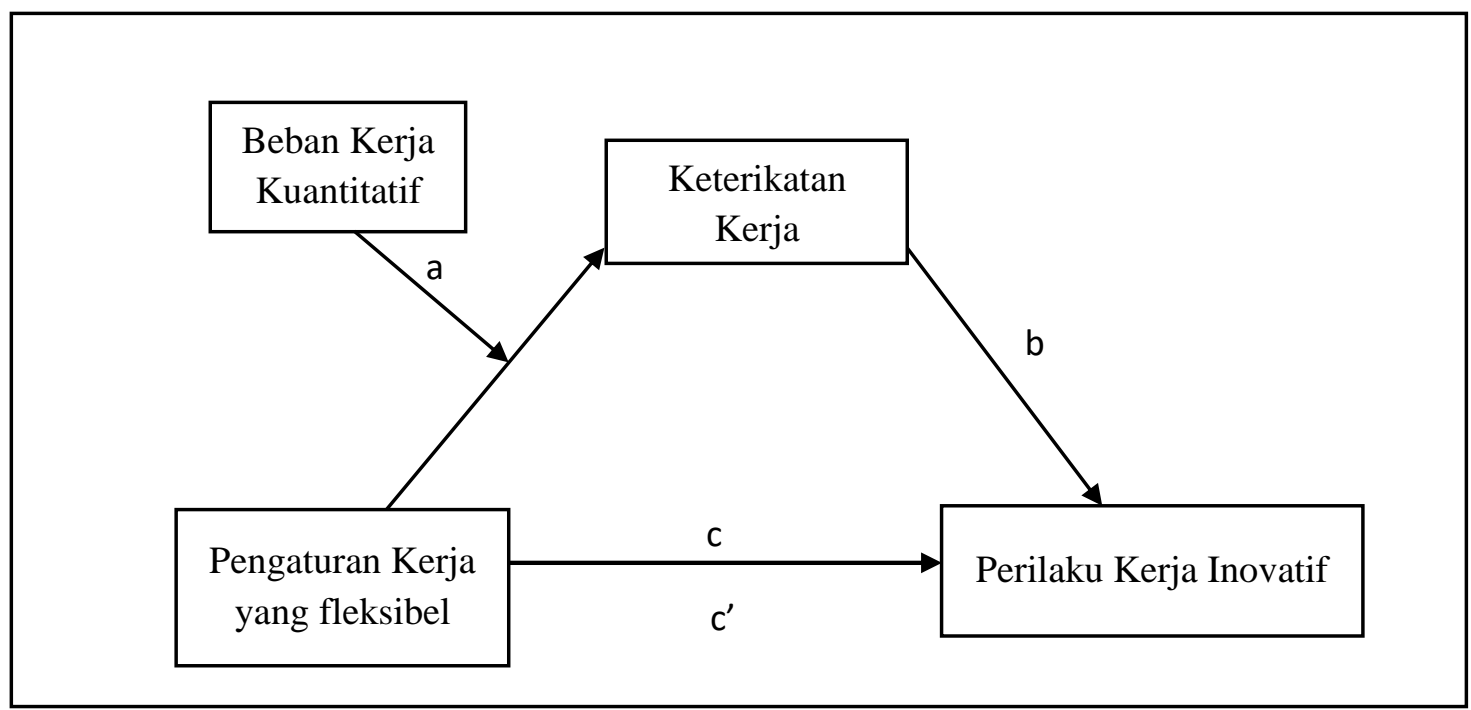

Figur 1. Model Penelitian

\section{Prosedur}

Sebelum kuesioner disebarkan, dilakukan kaji etik untuk memastikan penelitian dan kuesioner yang digunakan tidak melanggar hak asasi subjek penelitian. Formulir kaji etik disetujui oleh Tim Komite Etik dari Fakultas Psikologi Universitas Indonesia dengan nomor: 788/FPsi.Komite Etik/PDP.04.00/2020. Studi dilakukan dengan menyebarkan kuesioner secara daring menggunakan Google Form. Tautan Google Form disebarkan melalui media WhatsApp, Instagram, Linkedin, Facebook, dan Twitter. Untuk memastikan partisipan memahami hak dan perannya dalam penelitian ini, dijelaskan pada awal kuesioner bahwa keterlibatan partisipan bersifat sukarela, sehingga partisipan dapat mengundurkan diri kapanpun dalam penelitian ini. Disediakan juga kupon undian Gopay atau Ovo sejumlah Rp 50.000,00 untuk 20 orang partisipan yang dipilih acak sebagai apresiasi berpartisipasi. Informasi mengenai kupon undian tersebut dituliskan pada bagian awal kuesioner, namun menggunakan tautan yang terpisah dari tautan kuesioner sehingga respons yang diberikan partisipan dalam kuesioner tidak terhubung dengan identitas pribadi (nomor telepon) partisipan. Undian dilakukan pada akhir penelitian dan partisipan terpilih dihubungi oleh peneliti.

\section{Instrumen}

Berdasarkan variabel yang diteliti, terdapat empat kuesioner yang digunakan dalam penelitian. Untuk mengukur perilaku kerja inovatif digunakan skala Innovative Work Behavior yang 
dikembangkan oleh Janssen (2000) yang kemudian diadaptasi ke dalam bahasa Indonesia oleh Etikariena dan Muluk (2014) dengan koefisien Cronbach's Alpha .80. Alat ukur ini berjumlah 9 butir dengan menggunakan skala Likert 1-6 (1= "Sangat Tidak Sesuai”; 6 = "Sangat Sesuai"). Alat ukur kemudian diukur kembali reliabilitasnya pada sampel studi ini dan ditemukan koefisien Cronbach's Alpha sebesar .94, yang artinya reliabel untuk partisipan penelitian dengan sampel yang dimaksud. Contoh butir pernyataan yang digunakan untuk mengukur perilaku kerja inovatif adalah "Menciptakan ide baru untuk pengembangan tugas atau organisasi saya", "Menampilkan solusi yang belum pernah ditampilkan orang lain dalam mengatasi masalah", "Meninjau kembali kegunaan dari ide baru yang pernah saya ajukan di pekerjaan".

Untuk mengukur sikap karyawan dalam menerapkan pengaturan kerja yang fleksibel (flexible work arrangement), digunakan Flexible Work Options Questionnaire (FWOQ) yang dikembangkan oleh Albion (2004). Alat ukur ini terdiri dari empat dimensi, yakni keseimbangan kehidupan dan pekerjaan (work life balance) (contoh butir: "Pengaturan kerja yang fleksibel membantu saya untuk menyeimbangkan pekerjaan dengan kehidupan pribadi saya"), hambatan yang berkaitan dengan pandangan rekan kerja dalam kantor (barriers - others) (contoh butir: "Rekan kerja saya menunjukkan respons negatif terhadap pengaturan kerja yang fleksibel"), hambatan yang berkaitan dengan keuangan dan biaya (barriers - cost) (contoh butir: "Saya tidak mampu menanggung kerugian finansial akibat pengaturan kerja fleksibel yang melibatkan pengurangan jam kerja"), dan hambatan yang berkaitan dengan perasaan disosiasi dan komitmen terhadap tempat kerja (barriers commitment) (contoh butir: “Orang-orang yang menerapkan pengaturan kerja yang fleksibel biasanya kurang memiliki komitmen terhadap pekerjaannya"). Alat ukur ini terdiri dari 13 butir pernyataan. Hasil uji reliabilitas menghasilkan koefisien Cronbach's Alpha sebesar .75 setelah satu butir (nomor 13) dihapus karena nilai corrected item-total correlation di bawah standar $(<.2)$. Alat ukur ini menggunakan skala Likert dari 1-6 (1 = "Sangat Tidak Setuju; 6 = "Sangat Setuju").

Untuk mengukur keterikatan kerja digunakan Utrecht Work Engagement Scale (UWES) Short Version yang dikembangkan oleh Schaufeli dkk. (2006) dan kemudian diadaptasi oleh Novena (2013). Alat ukur yang terdiri dari sembilan butir pernyataan yang mengukur vigor (contoh butir: "Saya memiliki banyak energi ketika berada di tempat kerja"), dedication (contoh butir: "Saya bangga terhadap pekerjaan yang saya lakukan"), dan absorption (contoh butir: "Ketika sedang bekerja saya merasa larut dalam pekerjaan saya") menggunakan skala Likert dengan pilihan jawaban 1-6 (1 = "Sangat Tidak Sesuai”; 6 = "Sangat Sesuai”). Hasil uji reliabilitas menghasilkan koefisien Cronbach's Alpha sebesar .88. 
Keempat, untuk mengukur beban kerja kuantitatif digunakan Quantitative Workload Inventory (QWI) yang mengukur tempo dan volume atau banyaknya pekerjaan yang dirasakan oleh karyawan. Alat ukur ini dikembangkan oleh Spector dan Jex (1998) yang kemudian diadaptasi oleh Manuaba dan Hidayat (2019). Alat ukur ini terdiri dari 5 butir pertanyaan (contoh butir: "Seberapa sering perusahaan menuntut Anda bekerja dengan sangat cepat?") dengan menggunakan skala Likert dari 1-6 (1 = “Tidak Pernah"; 6 = "Beberapa Kali Perhari”). Alat ukur ini memiliki koefisien Cronbach's Alpha sebesar .87.

\section{Teknik Analisis}

Uji hipotesis dilakukan melalui analisis mediasi-moderasi model yang digunakan adalah model 7 moderated mediation, dengan tingkat kepercayaan 95\% dan estimasi 5.000 bootstrap sample. Model tersebut digunakan untuk melihat pengaruh kondisional, yaitu ketika terjadi pengaruh tidak langsung dari variabel independen pada variabel dependen melalui mediator yang bergantung pada moderator (Hayes, 2018). Program yang digunakan adalah Macro Process dari Hayes (2018) yang dipasangkan pada perangkat lunak SPSS versi 23.0.

\section{HASIL}

Pada tahap awal dilakukan analisis pendahuluan, yakni analisis statistik deskriptif, reliabilitas, serta korelasi Pearson's Product Moment dari keseluruhan alat ukur dalam penelitian ini. Tabel 2 menunjukkan statistik deskriptif tiap variabel. Seluruh variabel penelitian memiliki koefisien Cronbach's Alpha yang baik, yakni $\alpha>.7$ (Nunnally \& Bernstein, 1994). Berdasarkan hasil korelasi Pearson's Product Moment, diketahui bahwa korelasi positif yang signifikan hanya terjadi pada perilaku kerja inovatif dengan pengaturan kerja yang fleksibel dan keterikatan kerja. Kendati demikian, pada penelitian ini dilakukan uji model, sehingga pada akhirnya hubungan seluruh variabel dilihat secara keseluruhan sebagai suatu model dan tidak terpisah (Hayes, 2018). 
Tabel 2.

Statistik Deskriptif dan Korelasi Antar Variabel

\begin{tabular}{ccccccc}
\hline Variabel & Mean & SD & $\begin{array}{c}\text { Perilaku } \\
\text { Kerja } \\
\text { Inovatif }\end{array}$ & $\begin{array}{c}\text { Pengaturan } \\
\text { Kerja yang } \\
\text { Fleksibel }\end{array}$ & $\begin{array}{c}\text { Keterikatan } \\
\text { Kerja }\end{array}$ & $\begin{array}{c}\text { Beban } \\
\text { Kerja } \\
\text { Kuantitatif }\end{array}$ \\
\hline Perilaku kerja inovatif & 42.23 & 7.20 & 1 & & & \\
Pengaturan Kerja yang & 53.23 & 8.04 & $.14^{*}$ & 1 & & \\
fleksibel & 44.12 & 5.78 & $.59^{*}$ & .10 & 1 & \\
Keterikatan kerja & 16.76 & 5.21 & .10 & -.11 & .00 & 1 \\
Beban kerja kuantitatif &
\end{tabular}

Catatan: ${ }^{*}=$ Signifikan pada level $.05 ;^{* *}=$ Signifikan pada level .01. Perilaku kerja inovatif merupakan skor total dari Innovative Work Behavior (Janssen, 2000); pengaturan kerja yang fleksibel merupakan skor total dari FWOQ (Albion, 2004); keterikatan kerja merupakan skor total dari UWES (Schaufeli dkk., 2006); beban kerja kuantitatif merupakan skor total dari QWI (Spector \& Jex, 1998)

Selanjutnya, hasil uji hipotesis dapat dilihat melalui tiga jalur, yakni ketika keterikatan kerja sebagai variabel dependen (jalur a), perilaku kerja inovatif sebagai variabel dependen (jalur b \& c), dan hasil analisis model secara keseluruhan moderated mediation (jalur c').

Tabel 3 menunjukkan hasil analisis pada jalur a, yaitu hubungan yang signifikan antara pengaturan kerja yang fleksibel dengan keterikatan kerja, hubungan antara beban kerja kuantitatif dengan keterikatan kerja, dan adanya hubungan interaksi antara pengaturan kerja yang fleksibel dan beban kerja kuantitatif pada keterikatan kerja yang signifikan.

Tabel 3.

Hasil Analisis Moderasi Beban Kerja Kuantitatif antara Pengaturan Kerja yang Fleksibel (FWA) dan Keterikatan Kerja

\begin{tabular}{cccccc}
\hline & Coeff & $\boldsymbol{S E}$ & $\boldsymbol{t}$ & $\boldsymbol{L L C I}$ & $\boldsymbol{U L C I}$ \\
\hline Constant & 18.41 & 7.81 & $2.36^{*}$ & 3.04 & 33.79 \\
Pengaturan kerja yang & .48 & .14 & $3.32^{* *}$ & .19 & .76 \\
fleksibel & 1.30 & .44 & $2.94^{* *}$ & .43 & 2.17 \\
Beban kerja kuantitatif & -.02 & .01 & $-2.95^{* *}$ & -.04 & -.01 \\
Interaksi & &
\end{tabular}

Catatan: ${ }^{*}=$ Signifikan pada level $.05 ;{ }^{* * *}=$ Signifikan pada level .01. Pengaturan kerja yang fleksibel merupakan skor total dari FWOQ (Albion, 2004); beban kerja kuantitatif merupakan skor total dari QWI (Spector \& Jex, 1998)

Setelah diketahui adanya hubungan interaksi, dilakukan analisis lanjutan untuk melihat tingkat beban kerja kuantitatif yang dapat memengaruhi keterikatan kerja berdasarkan tingkat mean dan \pm 1 standar deviasi (SD) dari mean. Mengingat koefisien interaksi yang bernilai negatif, hasil menunjukkan bahwa interaksi hanya terjadi ketika beban kerja kuantitatif berada pada tingkat - 1 SD. Lebih lanjut, diketahui bahwa interaksi terjadi ketika Beban Kerja Kuantitatif < 16.09 dari total skor QWI. Melalui hal tersebut, diketahui bahwa beban kerja kuantitatif berperan sebagai moderator pada 
tingkat rendah. Hal ini dapat diartikan bahwa semakin rendah tingkat beban kerja kuantitatif, maka semakin tinggi pengaruh pengaturan kerja yang fleksibel terhadap keterikatan kerja.

Selanjutnya, dilakukan analisis untuk melihat hubungan langsung dari pengaturan kerja yang fleksibel dan keterikatan kerja dengan perilaku kerja inovatif. Tabel 4 menunjukkan hasil analisis ketika perilaku kerja inovatif berperan sebagai variabel dependen (jalur b \& c'). Diketahui bahwa tidak terdapat hubungan langsung yang signifikan antara pengaturan kerja yang fleksibel dengan perilaku kerja inovatif. Sementara itu, terdapat hubungan langsung yang signifikan antara keterikatan kerja dengan perilaku kerja inovatif.

Tabel 4.

Hasil Analisis Ketika Perilaku Kerja Inovatif Berperan sebagai Variabel Dependen

\begin{tabular}{cccccc}
\hline & Coeff & SE & $\boldsymbol{t}$ & LLCI & ULCI \\
\hline Constant & 6.34 & 3.48 & 1.82 & -.52 & 13.20 \\
Pengaturan kerja yang fleksibel & .07 & .05 & 1.60 & -.02 & .16 \\
Keterikatan kerja & .73 & .06 & $11.61^{* *}$ & .60 & .85 \\
\hline
\end{tabular}

Catatan: ${ }^{*}=$ Signifikan pada level $.05 ;{ }^{* * *}=$ Signifikan pada level .01. Pengaturan kerja yang fleksibel merupakan skor total dari FWOQ (Albion, 2004); keterikatan kerja merupakan skor total dari UWES (Schaufeli dkk., 2006)

Setelah mengetahui hubungan langsung dari pengaturan kerja yang fleksibel dan keterikatan kerja terhadap perilaku kerja inovatif, dilakukan uji keseluruhan model dengan melihat peran keterikatan kerja pada tingkat beban kerja kuantitatif tertentu dengan perilaku kerja inovatif. Tabel 5 menunjukkan hasil analisis keseluruhan model moderated mediation (jalur c). Diketahui bahwa keterikatan kerja berperan sebagai mediator yang dimoderasi oleh beban kerja kuantitatif pada hubungan antara pengaturan kerja yang fleksibel (FWA) dengan perilaku kerja inovatif, sehingga dapat disimpulkan bahwa hipotesis penelitian diterima. Lebih lanjut, mediasi yang terjadi adalah total mediasi dengan melihat bahwa hubungan antara pengaturan kerja yang fleksibel dengan perilaku kerja inovatif yang pada awalnya tidak signifikan, menjadi signifikan dengan memasukkan peran keterikatan kerja sebagai mediator yang dimoderasi oleh beban kerja kuantitatif.

Tabel 5.

Hasil Analisis Model Keseluruhan pada Tingkat Moderator Berbeda

\begin{tabular}{ccccc}
\hline $\begin{array}{c}\text { Beban Kerja } \\
\text { Kuantitatif }\end{array}$ & Effect & BootSE & BootLLCI & BootULCI \\
\hline $11.55(-1 \mathrm{SD})$ & .14 & .05 & .04 & .24 \\
$16.76($ mean $)$ & .05 & .03 & -.02 & .12 \\
$21.98(+1 \mathrm{SD})$ & -.04 & .05 & -.14 & .06 \\
\hline
\end{tabular}




\section{DISKUSI}

Hasil penelitian ini menunjukkan bahwa keterikatan kerja berperan sebagai mediator yang dimoderatori oleh beban kerja kuantitatif dalam hubungan antara pengaturan kerja yang fleksibel (FWA) dengan perilaku kerja inovatif. Hal ini berarti karyawan yang merasakan beban kerja yang rendah dapat meningkatkan efek positif dari pengaturan kerja yang fleksibel pada keterikatan kerja, yang akhirnya akan berdampak pada peningkatan perilaku kerja inovatif karyawan. Dengan demikian, meskipun secara model penelitian temuan ini selaras dengan Model JD-R, yaitu beban kerja kuantitatif (job demands) dapat berperan sebagai moderator antara pengaturan kerja yang fleksibel (dan keterikatan kerja (Bakker \& Demerouti, 2017). Namun, pada temuan ini beban kerja kuantitatif berperan sebagi moderator ketika terjadi pada tingkat yang rendah. Sementara itu, pada Model JD-R, semakin tinggi beban kerja kuantitatif yang dirasakan oleh karyawan, dapat memperkuat pengaruh pengaturan kerja yang fleksibel dengan keterikatan kerja, sehingga hasil yang didapatkan secara umum tidak selaras dengan Model JD-R. Pada awalnya, Model JD-R dengan proposisi yang melibatkan beban kerja sebagai upaya untuk meningkatkan pengaruh dari sumber daya pekerjaan dengan keterikatan kerja dilakukan dalam konteks pekerjaan pengajar (guru) dan dokter gigi (Bakker \& Demerouti, 2017). Kendati demikian, model ini juga menekankan bahwa dibutuhkan adanya sumber daya pekerjaan yang berguna (sesuai konteks lingkungan), sehingga dengan adanya beban kerja dapat meningkatkan pengaruh dari sumber daya pekerjaan tersebut. Pada penelitian ini, sumber daya pekerjaan berupa pengaturan kerja yang fleksibel masih kurang kuat dan relevan untuk membuat karyawan menjadi terikat dengan pekerjaannya sehingga beban kerja yang rendah dapat membantu karyawan menjadi lebih terikat.

Hal ini juga dapat dilihat dari dua sisi yang terdampak dari penerapan pengaturan kerja yang fleksibel. Dilihat dari sisi perusahaan, pengaturan kerja yang fleksibel adalah hal yang baru dan dilakukan karena kebijakan dari pemerintah di Indonesia. Sementara dari sisi karyawan, tampaknya beberapa karyawan belum memiliki kesiapan, sehingga pengaturan kerja yang fleksibel dapat mengakibatkan stres kerja (Himawan dkk., 2020). Hal tersebut didukung dengan pengakuan beberapa karyawan yang memiliki pengalaman negatif karena penerapan pengaturan kerja yang fleksibel membuat beban kerja menjadi semakin bertambah (Fachriansyah, 2020). Oleh karena itu, semakin rendah beban kerja kuantitatif yang dihadapi karyawan, pengaruh pengaturan kerja yang fleksibel terhadap keterikatan kerja karyawan akan semakin kuat. 
Chen dan Fulmer (2017) juga menyebutkan bahwa ketika perusahaan memilih untuk menerapkan pengaturan kerja yang fleksibel, karyawan akan merasa lebih dihargai, sehingga akan memunculkan perilaku kerja yang positif. Sementara penerapan pengaturan kerja yang fleksibel di Indonesia bagi beberapa perusahaan, dilakukan karena tuntutan kebijakan pemerintah dalam menghadapi dan memutus penyebaran penularan COVID-19. Hal tersebut menjadikan pengaturan kerja yang fleksibel sebagai sebuah kewajiban yang harus dilakukan perusahaan, bukan kebijakan yang dipilih oleh perusahaan dalam upaya memberikan penghargaan kepada karyawannya. Oleh karena itu, dalam penelitian ini, karyawan cenderung tidak merasa bahwa pengaturan kerja yang fleksibel dilakukan perusahaan sebagai upaya untuk memberdayakan dan memberikan penghargaan bagi karyawan, sehingga beban kerja kuantitatif yang tinggi dapat menghambat karyawan untuk merasa terikat dengan pekerjaannya. Selain itu, pandemi COVID-19 memengaruhi faktor psikologis seseorang seperti munculnya rasa cemas terhadap kesehatan, keamanan, keluarga, keuangan, hingga pekerjaan (Taylor, 2019). Hal tersebut dapat menyebabkan stres bagi karyawan, sehingga adanya beban kerja kuantitatif yang rendah dapat membantu karyawan yang menerapkan pengaturan kerja yang fleksibel menjadi lebih terikat dengan pekerjaannya.

Kemudian, penerapan pengaturan kerja yang fleksibel saja tidak cukup untuk membuat karyawan memunculkan perilaku kerja inovatif. Karyawan perlu untuk merasakan keterikatan kerja akibat diberlakukannya pengaturan kerja yang fleksibel dengan beban kerja yang rendah. Hal ini disebabkan karena untuk menjadi inovatif, karyawan perlu merasakan absorption, yakni berkonsentrasi dan terlibat secara mendalam pada aktivitas pekerjaannya, sehingga dapat menciptakan ide maupun gagasan yang bermanfaat bagi pekerjaannya. Karyawan juga perlu untuk memiliki semangat dan ketahanan mental (vigor) untuk melakukan seluruh tahapan dari perilaku kerja inovatif. Tiga tahapan dalam perilaku kerja inovatif (penciptaan, promosi, implementasi ide) merupakan aktivitas yang tidak berurutan, sehingga karyawan dapat mengkombinasikan urutan dari tiga tahapan tersebut (Scott \& Bruce, 1994). Oleh karena itu, untuk dapat terlibat dalam keseluruhan aktivitas dari penciptaan ide sampai dengan implementasi ide, karyawan perlu merasakan semangat dan memiliki ketahanan mental. Selain itu, untuk menjadi inovatif karyawan juga perlu memiliki rasa antusias, bangga, dan tertantang mengenai pekerjaannya (dedication), sehingga karyawan merasa bahwa upaya yang dikeluarkan dapat memberikan manfaat bagi perusahaan. Ketiga hal ini (vigor, absorption, dan dedication) merupakan aspek-aspek dalam keterikatan kerja yang dapat memunculkan perilaku kerja inovatif. 
Ketika karyawan merasa bahwa tempo kerjanya rendah dan volume pekerjaannya yang lebih sedikit, penerapan pengaturan kerja yang fleksibel dapat membuat karyawan merasa lebih terikat dengan pekerjaannya, sehingga pada akhirnya karyawan dapat memunculkan perilaku kerja inovatif. Oleh karena itu, dalam menerapan sistem kerja yang fleksibel selama masa pandemi COVID-19, perusahaan dapat mempertimbangkan kembali beban kerja kuantitatif yang diberikan kepada karyawan. Mengingat untuk beberapa perusahaan, pengaturan kerja yang fleksibel merupakan hal yang baru, sehingga karyawan memerlukan waktu untuk beradaptasi dan dapat menjadi terikat dengan pekerjaannya. Apabila perusahaan menetapkan beban kerja kuantitatif yang rendah, maka karyawan yang menerapkan pengaturan kerja yang fleksibel dapat lebih terbantu untuk merasa terikat dengan pekerjaannya. Pada akhirnya, ketika karyawan merasakan keterikatan dengan pekerjaannya, karyawan dapat memunculkan perilaku kerja inovatif.

Penelitian ini memiliki beberapa keterbatasan yang dapat memengaruhi interpretasi hasil penelitian. Pertama, pengukuran penerapan kerja yang fleksibel dilakukan dengan latar belakang situasi Pandemi COVID-19, sehingga beberapa perusahaan menerapkan pengaturan kerja yang fleksibel karena keharusan dari peraturan pemerintah di Indonesia. Oleh karena itu, hasil yang didapatkan tidak dapat digeneralisasikan untuk seluruh karyawan dari perusahaan yang menerapkan pengaturan kerja yang fleksibel sebagai pilihan untuk meningkatkan efektifitas kerja. Kedua, alat ukur FWOQ yang mengukur sikap karyawan dalam menerapkan pengaturan kerja yang fleksibel akan lebih sesuai apabila digunakan untuk mengukur pengaturan kerja yang fleksibel yang diterapkan oleh perusahaan karena pilihan dari perusahaan, bukan karena kewajiban atau keharusan. Ketiga, penelitian ini terbatas mengukur perilaku karyawan dalam menanggapi pengaturan kerja yang fleksibel secara umum, sehingga belum diketahui dampak dari jenis pengaturan kerja yang fleksibel secara spesifik (seperti WFH, shifting). Keempat, pada penelitian ini tidak dilakukan kontrol variabel. Penelitian selanjutnya dapat melakukan kontrol variabel terkait jenis pengaturan kerja yang fleksibel yang diterapkan oleh perusahaan, lamanya perusahaan menerapkan pengaturan kerja yang fleksibel, serta memastikan pengaturan kerja yang fleksibel dilakukan karena dampak dari COVID-19 atau memang merupakan kebijakan perusahaan untuk meningkatkan produktivitas dan kesejahteraan karyawan. Kelima, jumlah butir yang banyak dalam alat ukur pada kuesioner dapat memberikan efek kelelahan bagi partisipan, sehingga memengaruhi akurasi respons yang diberikannya. 


\section{SIMPULAN DAN SARAN}

\section{Simpulan}

Berdasarkan penjabaran mengenai temuan dalam penelitian, dapat disimpulkan bahwa ketika karyawan merasakan beban kerja kuantitatif yang rendah, karyawan yang menerapkan pengaturan kerja yang fleksibel dapat lebih merasakan keterikatan dengan pekerjaannya, sehingga dapat memunculkan perilaku kerja inovatif.

\section{Saran Teoretis}

Hasil dari penelitian ini dapat memperluas pengetahuan mengenai perilaku kerja inovatif, khususnya dalam menghadapi situasi pandemi COVID-19. Kendati demikian, pemilihan sampel pada penelitian ini tidak dibedakan antara karyawan yang baru saja menerapkan pengaturan kerja yang fleksibel karena terdampak COVID-19 dan karyawan yang telah menerapkan pengaturan kerja yang fleksibel karena upaya perusahaan dalam menghargai karyawannya. Oleh karena itu, penelitian selanjutnya dapat memilih antara populasi yang sedang mencoba untuk menerapkan pengaturan kerja yang fleksibel (masa transisi) atau yang telah menerapkan pengaturan kerja yang fleksibel, sehingga perbedaan tersebut tidak berdampak pada hasil penelitian. Selain itu, penelitian selanjutnya juga dapat meneliti terkait jenis pengaturan kerja yang fleksibel secara lebih spesifik (seperti WFH, shifting), sehingga dapat diketahui perbedaan antara jenis penerapan pengaturan kerja yang fleksibel.

\section{Saran Praktis}

Terdapat beberapa saran praktis yang dapat ditawarkan kepada perusahaan (manajemen) maupun karyawan, khususnya selama penerapan pengaturan kerja fleksibel pada periode pandemi COVID-19. Perusahaan diharapkan dapat melakukan analisis beban kerja sehingga dapat menyesuaikan tempo dan beban kerja karyawan selama penerapan pengaturan kerja yang fleksibel. Supervisor atau atasan juga dapat menyusun program kerja dengan mempertimbangkan beban kerja serta kesiapan karyawan, serta memberikan kepercayaan, sehingga proses pengawasan secara virtual dapat berjalan dengan efektif. 


\section{REFERENSI}

Agarwal, U. A., Datta, S., Blake-Beard, S., \& Bhargava, S. (2012). Linking LMX, innovative work behaviour and turnover intentions. Career development international, 17(3), 208230. https://doi.org/10.1108/13620431211241063

Albion, M. J. (2004). A measure of attitudes towards flexible work options. Australian Journal of Management, 29(2), 275-294. https://doi.org/10.1177/031289620402900207

Allen, T. D., \& Shockley, K. (2009). Flexible work arrangements: Help or hype. Handbook of families and work: Interdisciplinary perspectives, 265-284.

Anell, K., \& Hartmann, D. (2007). Flexible work arrangements in Asia. Boston College Center for Work \& Family. https://www.bc.edu/content/dam/files/centers/cwf/research/publications3 /researchreports/Flexible\%20Work\%20Arrangements\%20in\%20Asia

Bakker, A. B., \& Demerouti, E. (2014). Job demands-resources theory. Dalam Chen, P. Y., \& Cooper, C. L. (Eds.). Wellbeing: A complete reference guide, (pp. 1-28). John Wiley \& Sons. http://dx.doi.org/10.1002/9781118539415.wbwell019

Bakker, A. B., \& Demerouti, E. (2017). Job Demands-Resources Theory: Taking Stock and Looking Forward. Journal of Occupational Health Psychology, 22(3), 273-285. http://dx.doi.org/10.1037/ocp0000056

Chen, Y., \& Fulmer, I. S. (2017). Fine-tuning what we know about employees' experience with flexible work arrangements and their job attitudes. Human Resource Management, 57(1), 381-395. https://doi.org/10.1002/hrm.21849

De Spiegelaere, S., Van Gyes, G., \& Van Hootegem, G. (2016). Not all autonomy is the same. Different dimensions of job autonomy and their relation to work engagement $\&$ innovative work behavior. Human Factors and Ergonomics in Manufacturing \& Service Industries, 26(4), 515-527. https://doi.org/10.1002/hfm.20666

Dinas Ketenagakerjaan dan Transmigrasi DKI Jakarta. (2020, April 15). Jumlah pelaporan perusahaan yang telah melaksanakan wfh/psbb sampai dengan 15 april 2020. https://www.instagram.com/p/B-_IdaljCJU/?igshid=s2gz2itslzcg

Etikariena, A., \& Muluk, H. (2014). Hubungan antara memori organisasi dan perilaku inovatif karyawan. Makara Hubs-Asia, 18(2), 77-88. https://doi.org/10.7454/mssh.v18i2.3463

Fachriansyah, R. (2020). Coronavirus means working from home for many, but some say it's easier said than done. The Pakarta 
https://www.thejakartapost.com/news/2020/04/08/coronavirus-means-working-from-homefor-many-but-some-say-its-easier-said-than-done.html

Faul, F., Erdfelder, E., Lang, A.G., \& Buchner, A. (2007). G*Power 3: A flexible statistical power analysis program for the social, behavioral, and biomedical sciences. Behavior Research Methods, 39(2), 175-191. https://doi.org/10.3758/BF03193146

Finn, B. (2020, 4 April). Innovation in a time of crisis: How business are responding to COVID-19. Raidio Teilifs Eireann. https://www.rte.ie/news/business/2020/0403/1128372-innovation-ina-crisis-businesses-respond-to-COVID-19/

Gravetter, F. J., \& Forzano, L. A. B. (2012). Research methods for the behavioral sciences (4th ed.). Wadsworth Cengage Learning.

Hayes, A. F. (2018). Introduction to mediation, moderation, and conditional process analysis: A regression-based approach. Guilford.

Hayman, J. R. (2009). Flexible work arrangements: Exploring the linkages between perceived usability of flexible work schedules and work/life balance. Community, work \& family, 12(3), 327-338.

Himawan, K., Fanggidae, J. P., \& Helmi, J. (2020). The sociocultural barriers of work-from-home arrangement due to COVID-19 pandemic in Asia: Implications and future implementation. advance. Advance. https://doi.org/10.31124/advance.12250190.v1

Janssen, O. (2000). Job demands, perceptions of effort-reward fairness and innovative work behaviour. Journal of Occupational and Organizational Psychology,73(3), 287-302. https://doi.org/10.1348/096317900167038

Kossek, E. E., Lautsch, B. A., \& Eaton, S. C. (2006). Telecommuting, control, and boundary management: Correlates of policy use and practice, job control, and work-family $\begin{array}{llll}\text { effectiveness. Journal } & \text { of } \quad \text { Vocational } & \text { Behavior, 68(2), }\end{array}$ https://doi.org/10.1016/j.jvb.2005.07.002

Lang, H. (2020, 18 Maret). Industries need to innovate to survive the coronavirus lockdown. Xeim. https://www.marketingweek.com/harry-lang-innovate-coronavirus/

Laucereno, S. F. (2020, 12 Maret). Sederet dampak corona terhadap bisnis di Indonesia. Detik Finance. https://finance.detik.com/berita-ekonomi-bisnis/d-4935727/sederet-dampakcorona-terhadap-bisnis-di-indonesia 
Mehta, K. (2020, 9 Maret). Why coronavirus will stimulate innovation. Forbes. https://www.forbes.com/sites/kmehta/2020/03/09/why-coronavirus-will-stimulateinnovation/\#5b8d1d8f2283

Manuaba, I. A. K. A., \& Hidayat, A. E. (2019, August). Increasing the engagement of millennials: finding autonomy and salience in high workload. [Paper presentation]. 2nd International Conference on Intervention and Applied Psychology (ICIAP 2018), Indonesia. https://doi.org/10.2991/iciap-18.2019.71

Messmann, G., Stoffers, J., Van der Heijden, B., \& Mulder, R. H. (2017). Joint effects of job demands and job resources on vocational teachers' innovative work behavior. Personnel Review, 46 (8), 1948-1961. https://doi.org/10.1108/PR-03-2016-0053

Novena, M. M. (2013). Program intervensi untuk meningkatkan keterikatan kerja di perusahaan XYZ berdasarkan variabel keadilan prosedural, ketahanan psikologis dan komitmen untuk berubah. (Tesis tidak dipublikasikan). Universitas Indonesia, Depok.

Nunally, J. C., \& Bernstein, I. H. (1994). Psychometric Theory (3rd ed). New York: McGraw-Hill.

Park, Y. K., Song, J. H., Yoon, S. W., \& Kim, J. (2014). Learning organization and innovative behavior: The mediating effect of work engagement. European Journal of Training and Development, 38(1-2), 75-94. https://doi.org/10.1108/EJTD-04-2013-0040

Schaufeli, W. B., Bakker, A. B., \& Salanova, M. (2006). The measurement of work engagement with a short questionnaire: A cross-national study. Educational and psychological measurement, 66(4), 701-716. https://doi.org/10.1177/0013164405282471

Scott, S. G., \& Bruce, R. A. (1994, October). Creating innovative behavior among $R \& D$ professionals: the moderating effect of leadership on the relationship between problemsolving style and innovation. [Paper presentation]. Proceedings of 1994 IEEE International Engineering Management Conference-IEMC'94, USA.

Shockley, K. M., \& Allen, T. D. (2007). When flexibility helps: Another look at the availability of flexible work arrangements and work-family conflict. Journal of Vocational Behavior, 71(3), 479-493. https://doi.org/ 10.1016/j.jvb.2007.08.006

Spector, P. E., \& Jex, S. M. (1998). Development of four self-report measures of job stressors and strain: interpersonal conflict at work scale, organizational constraints scale, quantitative workload inventory, and physical symptoms inventory. Journal of occupational health psychology, 3(4), 356-367. https://doi.org/10.1037//1076-8998.3. 
Taylor, S. (2019). The psychology of pandemics: Preparing for the next global outbreak of infectious disease. Cambridge.

Ugargol, J. D., \& Patrick, H. A. (2018). The relationship of workplace flexibility to employee engagement among information technology employees in India. South Asian Journal of Human Resources Management, 5(1), 40-55. https://doi.org/10.1177/2322093718767469

Worldometer. (2020, April 15). Coronavirus: Indonesia. https://www.worldometers.info/coronavirus/country/indonesia/ 